\title{
THE ECONOMICS OF BIOGAS PRODUCTION
}

\author{
KH.S. KARIMOV ${ }^{1,2}$, M. ABID ${ }^{1}$, S.I. ISLOMOV ${ }^{3}$, N.H. KARIMOVA ${ }^{3}$ \\ AND M.W. AL-GRAFI ${ }^{4}$ \\ ${ }^{1}$ GIK Institute of Engineering Sciences and Technology, Topi, Pakistan. \\ ${ }^{2}$ Physical Technical Institute of Academy of Sciences, Tajikistan. \\ ${ }^{3}$ Institute of Economics of Academy of Sciences of Tajikistan, Dushanbe, Tajikistan. \\ ${ }^{4}$ Department of Mechanical Engineering, Taibah University, \\ Al-Madina Al-Munawara, Saudi Arabia.
}

khasan@giki.edu.pk,abid@giki.edu.pk

\begin{abstract}
This paper assesses the life-cycle cost analysis of three biogas digesters. Results show that the cost of biogas depends on the construction of digesters, sizes of methane tank and possibility of heating of the slurry. The biogas and natural gas cost calculations are observed and found to be comparable. Therefore, it is recommended that the biogas digesters can be constructed and installed even by every family where the forming of long gas pipelines is not required and/or compulsory.
\end{abstract}

ABSTRAK: Kertaskerja ini membentangkan analisis kos kitar hayat tiga pencerna biogas. Keputusan menunjukkan kos biogas bergantung kepada pembinaan pencerna, saiz tangki metana dan kemungkinan pemanasan buburan. Pengiraan kos biogas dan gas asli diambil kira dan ianya didapati setanding. Adalah disarankan pencerna biogas boleh dibina dan dipasang secara teorinya, bagi setiap keluarga tanpa memerlukan pembinaan paip gas yang panjang.

KEYWORDS: Biogas; Digester; Slurry; Life-Cycle Costing; Annualized Life-Cycle Cost; Cost of Biogas; Natural Gas

\section{INTRODUCTION}

Solar energy is practically an inexhaustible source and can satisfy energy needs of the world for many centuries. Considerable attention has been paid in the industrially developed and developing countries to the utilization of solar energy present in biomass as a result of photosynthetic process [1-3]. In addition, environmental agencies demand proper processing of organic wastes to control problems of infection from the utilization of huge mass of dung from cattle-breeding farms. A recent trend in the power industry is the production of small-scale biogas plants, satisfying the needs of one or several families living in the countryside. However, in China, India and Sri Lanka large factories for the production of biogas that can supply electricity to the population of the whole village or settlement have been constructed. In addition, recently the most successful designs have appeared in Western Europe. An increasing trend of biogas technology is also observed in the developed countries. For example in Germany alone, during the last 17 years, the numbers of biogas plants have increased from 100 to 3500, i.e. 35 times [2], which is indeed a substantial increase (Fig. 1).

In Tajikistan, development of biogas technology is in its initial stages; though the country has been importing natural gas from Uzbekistan at a very high cost ( US $\$ 300$ per $\left.1000 \mathrm{~m}^{3}\right)$. Therefore at present it is very important to accelerate the installation of biogas 
digesters. For this, knowledge of economics of biogas technology will be very useful for the bio gasification in remote and rural areas. In this paper life-cycle costing (LCC) and annualized life-cycle cost (ALCC) approaches have been used to analyze the economics of three biogas digesters installed in Tajikistan and Pakistan.

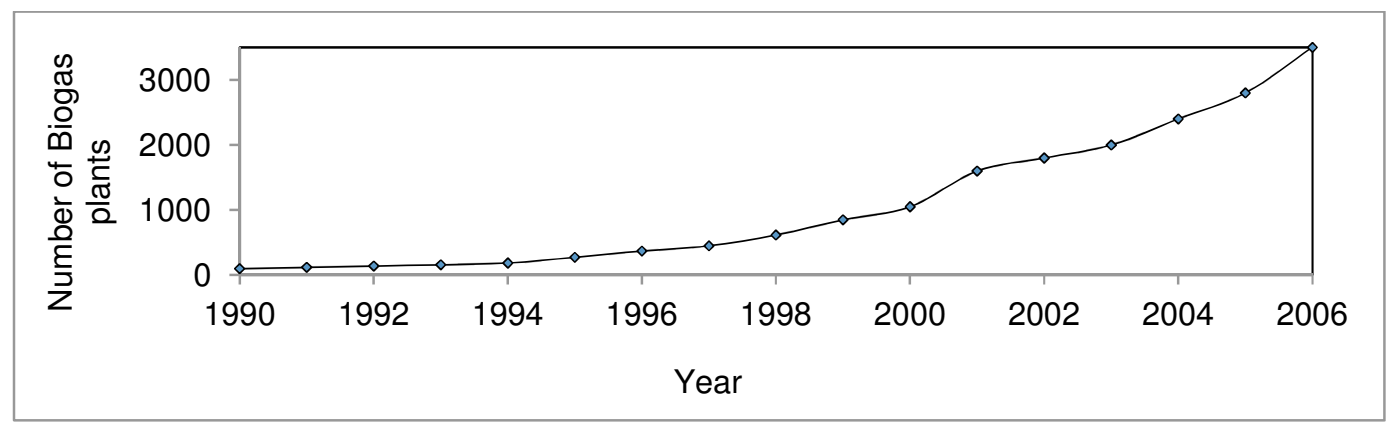

Fig. 1: Development of biogas industry in Germany from 1990 to 2006. [2]

\section{BIOGAS DIGESTER INSTALLED IN VAHDAT DISTRICT OF TAJIKISTAN}

Biogas digesters were constructed with the financial support of international organization ISAR and help of scientists of S.U. Umarov Physical Technical Institute of the Academy of Sciences of the Republic of Tajikistan in a private farm in Vahdat district (Fig. 2). This digester was made of metallic tanks of capacity $10 \mathrm{~m}^{3}$ and was filled up to $2 / 3$ of the volume with active biomass. This digester was equipped with manometers, safety gates and valves and was operated with all the safety precautions and regulations as required for natural gas. Retention time was 18 days during the summer season. The biogas product was used for cooking and electric power generation.

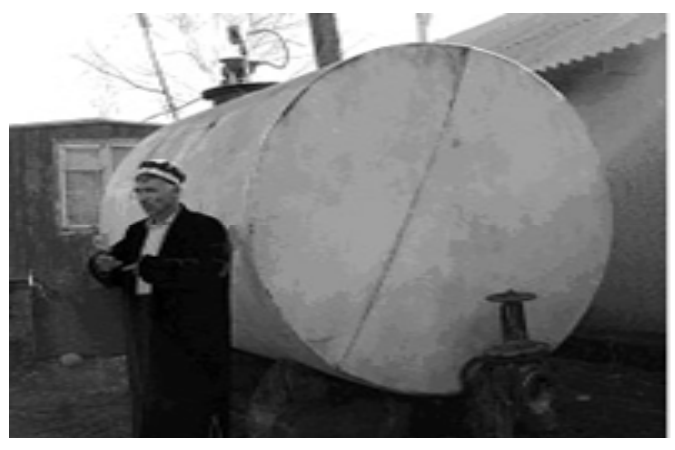

(a)

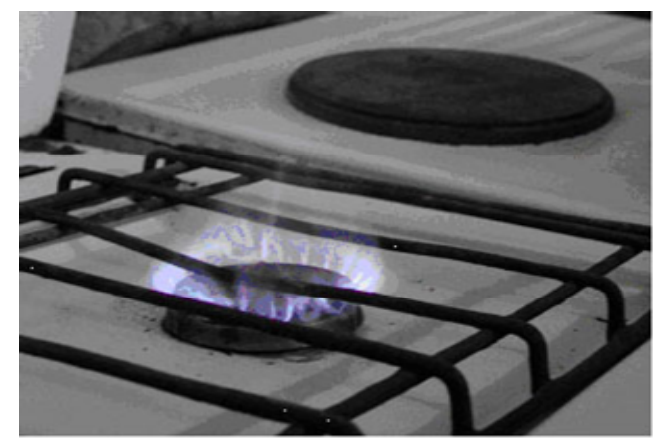

(b)

Fig. 2: Biogas digester installed: (a) in Vahdat village of Tajikistan, (b) and gas stove.

\section{BIOGAS DIGESTER INSTALLED IN RUDAKI DISTRICT OF TAJIKISTAN}

In the digester at Rudaki, methane tank and gas holder were mounted separately as shown in Fig. 3. In the middle of the methane tank, a mixer of special design was built to mix slurry. Methane tank of $10 \mathrm{~m}^{3}$ capacity was loaded with up to $80 \%$ by slurry. Retention time was 30 days in the winter. Biogas from methane tank to the point of consumption was transported through metallic pipes of $15-50 \mathrm{~mm}$ diameter. Productivity of 
the biogas from this digester was in the range of $6-9 \mathrm{~m}^{3}$ per day and was used for making buns (Fig. 4a) in an oven and generation of electric power using a low power electric generator (Fig. $4 \mathrm{~b}$ ). The residue in the digester after the production of biogas could be used as high quality fertilizer for agriculture.
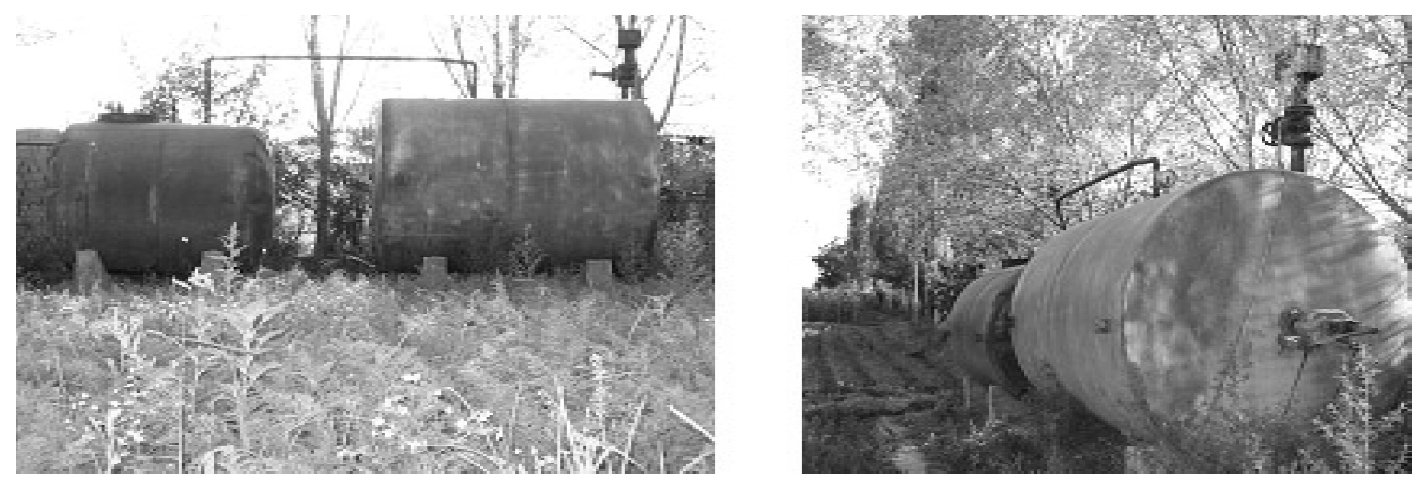

Fig. 3: Biogas digester installed in Rudaki district of Tajikistan.

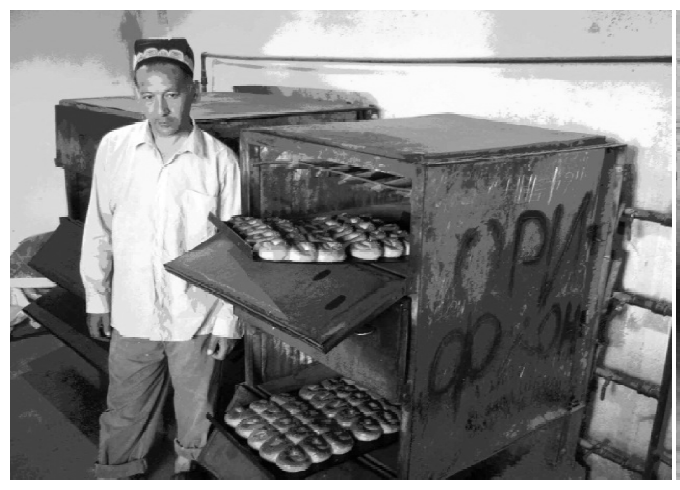

(a)

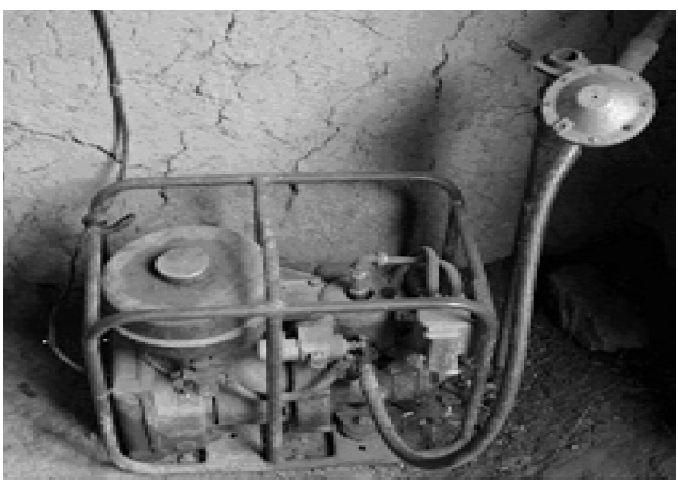

(b)

Fig. 4: (a) Buns prepared using biogas, (b) electric generator for production of electric power from biogas in Tajikistan.

\section{SOLAR BIOGAS DIGESTER FABRICATED IN GIK INSTITUTE OF PAKISTAN}

Earlier several solar biogas digesters were designed and fabricated by GIK Institute of Pakistanand in continuation with its efforts in design and fabricate solar biogas digesters. Investigations of more efficient solar biogas digester with built-in reverse absorber heater is presented here. The heating of slurry in biogas digester increases biogas production and decreases the retention time. The biogas digester consists of a methane tank with built-in solar reverse absorber heater to utilize solar energy for the heating of the slurry prepared from different organic wastes (dung, sewage, food wastes, etc.). The digester is of a laboratory scale and consists of a horizontal axes cylindrical metallic methane tank of size $0.8 \mathrm{~m}$ in diameter, $2 \mathrm{~m}$ in length and $1 \mathrm{~m}^{3}$ in volume with a solar reverse absorber heater installed under the methane tank. The absorber surface was blackened to increase absorption of solar irradiation. The solar reverse absorber heater consists of horizontal axes cylindrical reflecting mirror and horizontal glass cover. A horizontal absorber is a common element of the methane tank and solar reverse heater. A cylindrical reflector was used with a radius of $0.7 \mathrm{~m}$ and glazing area of $1.9 \times 0.7 \mathrm{~m}^{2}$. The 
outer surface of the digester was covered by thermo insulated material, aluminum foil and polymer film. The methane tank was filled up to $70 \%$ of its volume by organic wastes of the GIK institute sewage (70\%) and cow dung (30\%). Figures 5and 6 show the schematic diagrams and photograph of the solar biogas digester respectively. Elastic rubber tubes of volume of $0.5 \mathrm{~m}^{3}$ were used as gas storage containers.. The performance of the digester was investigated during the period (January-March, 2011). The solar irradiance incident to the absorber, slurry's temperature and ambient temperature were measured. Figure 8 shows slurry and ambient temperatures during 11 days in March 2011.
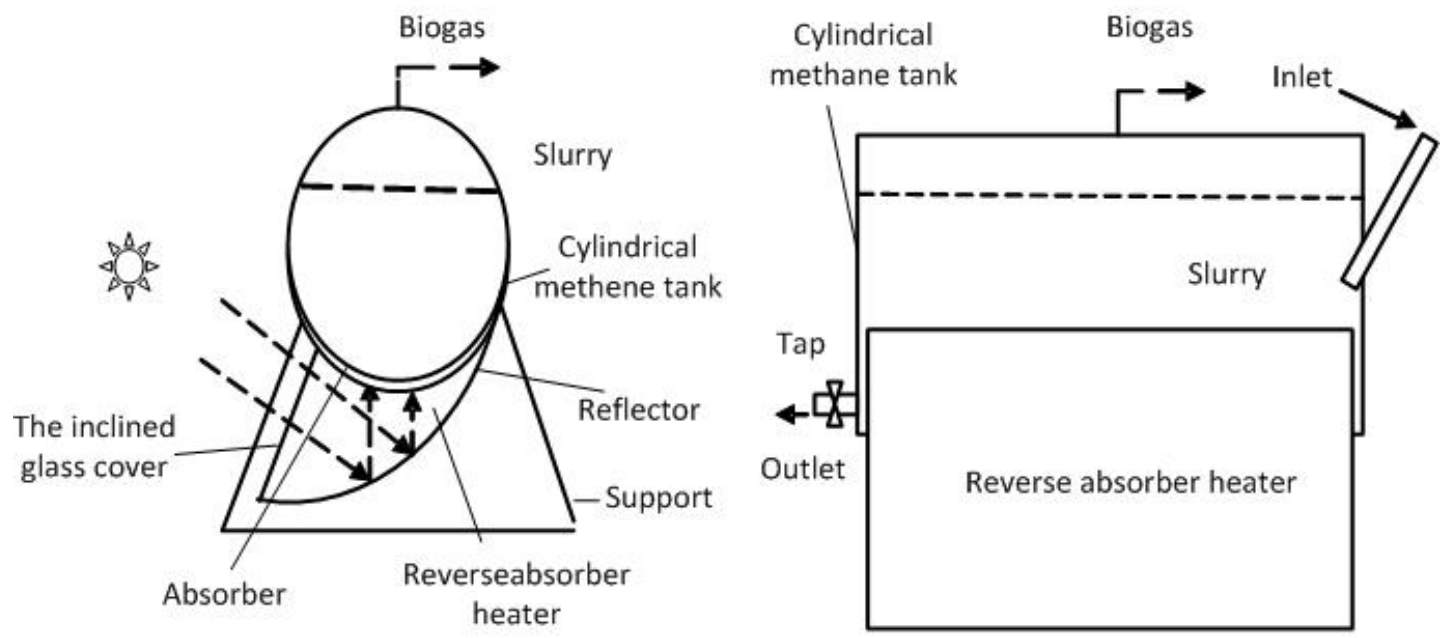

Fig. 5: Schematic diagram of solar biogas digester.

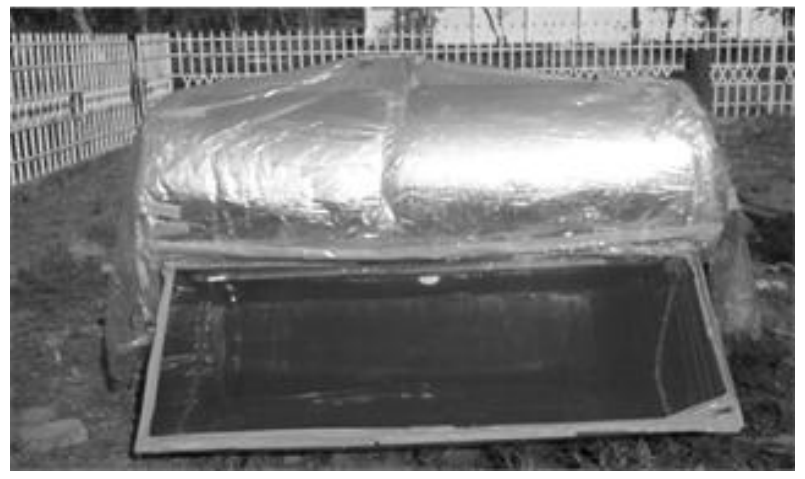

(a)

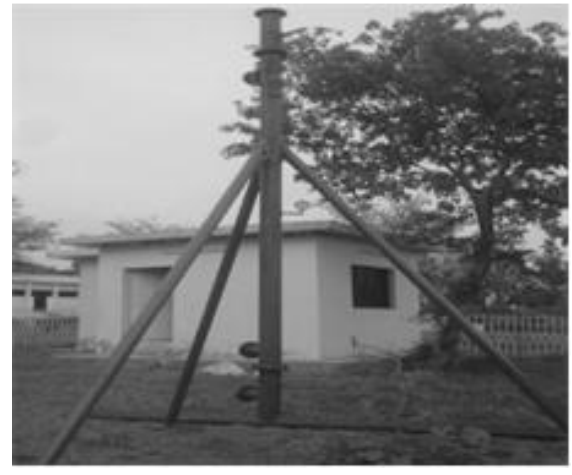

(b)

Fig. 6: (a) Solar biogas digester fabricated at GIK Institute of Pakistan, (b) Scrubbing tower for removal of carbon dioxide from biogas.

Figure 7 showsthat the slurry temperature is higher than the ambient temperature. It was found that using sewage and cow dung the retention time was almost 2 weeks and approximately $0.8-1.0 \mathrm{~m}^{3}$ of biogas was produced daily. Concentration of methane in the biogas on the average was approximately $74 \%$. Biogas was up graded by the removal of carbon dioxide, hydrogen sulphide and water vapor. Figure $6 \mathrm{~b}$ showsthe scrubbing tower for removal of carbon dioxide from biogas. This biogas digester may be used domestically as well as for demonstrative/teaching purposes. In addition, based on the results achieved it can be used for the construction of larger volume solar biogas digesters for use on farms, especially located in remote areas. 


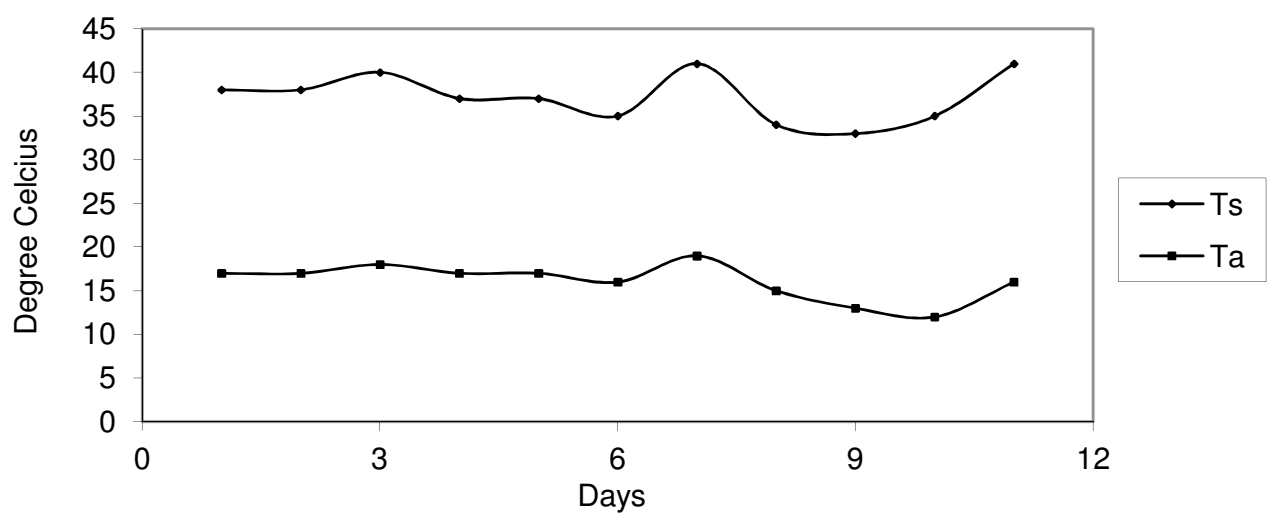

Fig. 7: Sludge $\left(\mathrm{T}_{\mathrm{S}}\right)$ and ambient $\left(\mathrm{T}_{\mathrm{a}}\right)$ temperatures during11 days in March 2011.

\section{COST ANALYSIS}

The cost of bio-gas was estimated on the basis of LCC and ALCC approaches described in [3] using the following expressions:

$P W=\operatorname{Cr} x \operatorname{Pr}$

where $P W$ is the present worth for a single future payment, Cris a single future cost, Pris a discount factor for a single future payment. In the case of repeating payments [3]:

$$
P W=C a x P a
$$

where $P W$ is the present worth for annual future payment, $C a$ is the annual future cost, $P a$ is a discount factor for annual future payment. The $P a$ and $P r$ is determined as [3]:

$\operatorname{Pr}=[(1+i) /(1+d)]^{N}$

and $P a=[(1+i) /(1+d)] \cdot\left\{[(1+i) /(1+d)]^{N}-1\right\} /\{[(1+i) /(1+d)]-1\}$

where $N$ is the period of analysis, $i$ is excess inflation and $d$ is discount rate.

The annualized life-cycle cost, ALCC $=\mathrm{LCC} / \mathrm{Pa}$

Considering digester's volume $\left(V_{d}\right)$ of $6.7 \mathrm{~m}^{3}$ with retention time $\left(t_{r}\right)$ of 18 days, the flow rate of fluid $\left(V_{f}\right)$ of $0.37 \mathrm{~m}^{3} \mathrm{day}^{-1}$ of the digester fluid is determined by [4] as:

$V_{f}=V_{d} / t_{r}$

The mass of dry input, $m_{o}=V_{f} \rho_{m}$

where $\rho_{m}$ is the density of the dry matter in the fluid $\left(\sim 50 \mathrm{kgm}^{-3}\right): \mathrm{m}_{0}=18.6 \mathrm{~kg} \mathrm{day}^{-1}$.

The daily produced biogas volume determined by [4] as; $V_{b}=\mathrm{cm}_{o}$

where $c$ is biogas yield per unit dry mass of whole input $\left(0.2-0.4 \mathrm{~m}^{3} \mathrm{~kg}^{-1}\right)$ and an average value of $V_{b}$ calculated using $\mathrm{Eq} .8$ is $5.6 \mathrm{~m}^{3}$. To the first approximation, the volume of daily produced biogas is equal to the digesters (or slurry's) volume, depending on the nature and composition of organic wastes.

Natural gas is composed of $\mathrm{CH}_{4}$ (up to $98 \%$ ), other components are $\left(\mathrm{C}_{2} \mathrm{H}_{6}\right),\left(\mathrm{C}_{3} \mathrm{H}_{8}\right)$, $\left(\mathrm{C}_{4} \mathrm{H}_{10}\right),\left(\mathrm{H}_{2}\right),\left(\mathrm{H}_{2} \mathrm{~S}\right),\left(\mathrm{CO}_{2}\right),\left(\mathrm{N}_{2}\right)$, and $(\mathrm{He})$. The standard accepted temperature and pressure of natural gas is $0^{\circ} \mathrm{C}$ and 1 bar respectively. Figure 8 shows large increase in natural gas price from $\$ 80$ to $\$ 280 /$ Thousand $\mathrm{m}^{3}$ in USA during the period1980 to 2005 . 
In the first approximation, as an average, the cost of the natural gas is comparable to cost of the methane (US $\$ 95 /$ Thousand $\mathrm{m}^{3}$ ) obtained from biogas. Life-cycle costing calculationsfor the three biogas digesters are given in Table 1.

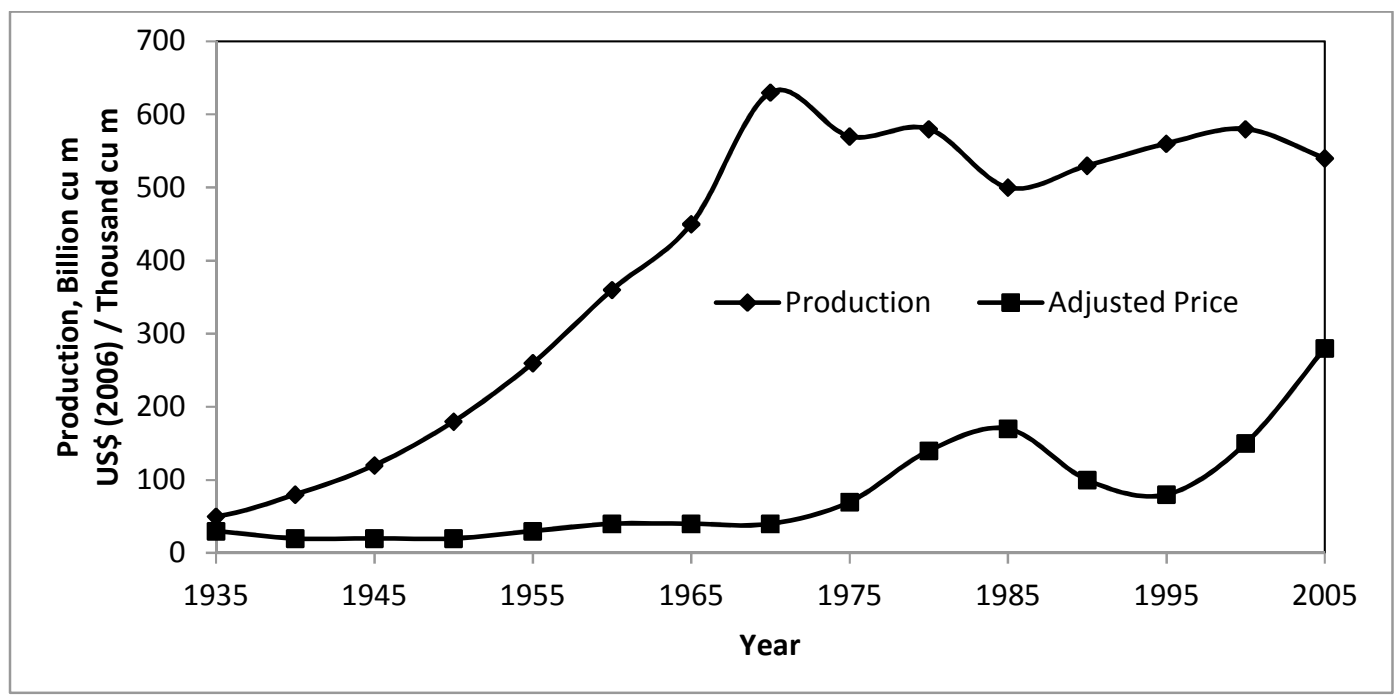

Fig. 8: Production and cost of natural gas in USA.

For biogas digesters of Vahdat and Rudaki districts of Tajikistan and GIK Institute of Pakistan, if a biogas digester produces gas 330 days in a year considering cleaning and slurry loading, and retention time for biogas production, the total produced gas will be $1848 \mathrm{~m}^{3}, 2640 \mathrm{~m}^{3}$ and $330 \mathrm{~m}^{3}$ respectively. From Eq. (9) the cost of $1000 \mathrm{~m}^{3}$ of biogas determined for Vahdat, Rudaki and GIKI areUS\$ 66.4, 60 and 75.8 respectively ;

Cost of biogas $=$ ALCC $/$ total produced gas

Considering $70 \%$ concentration of methane in the biogas produced at Vahdat and Rudaki digesters and 74\% at GIK Institute, the cost of methane extracted from biogas is US $\$ 95,86$ and 102 per thousand $\mathrm{m}^{3}$, respectively, with pressure usually of 0.1-0.2 bar. The cost of the biogas of the digester installed in Rudaki district is less than the installed in Vahdat district. It may be, firstly, due to the presence of the mixer that plays positive role, in the case of digester installed in Rudaki. Secondly, due to the presence of large volume gas-holder as it is well known that the rate of biogas production increases if pressure in the digester is lower (as in the case of the digester installed in Rudaki district) and decreases if pressure increases (as in the case of the digester installed in Vahdat district). The cost of biogas of the digester at GIK Institute is higher than installed in Vahdat and Rudaki districts. It may be, firstly, due to the small volume $\left(1 \mathrm{~m}^{3}\right)$ of the solar biogas digester with respect to the digesters in Vahdat and Rudaki districts $\left(10 \mathrm{~m}^{3}\right)$. Usually if the volume of the biogas digester is larger due to the exothermic reaction at anaerobic process the slurry is heated additionally and production of the biogas increases slightly [7,8]. At the same time experiments that were conducted with solar biogas digester and ordinary digester of the same volume of methane tank showed that in the case of solar biogas digester retention period was $15 \%$ less and biogas volume produced was 20\% higher [12]. Table 2 shows technical parameters and costs of biogas of the investigated digesters. 
Table 1: Life-cycle costing calculation sheet for the biogas digester installed in Vahdat district of Tajikistan, Rudaki district of Tajikistan and GIK Institute of Pakistan.

\begin{tabular}{|c|c|c|c|}
\hline & $\begin{array}{c}\text { Vahdat } \\
\text { Tajikistan }\end{array}$ & $\begin{array}{c}\text { Rudaki } \\
\text { Tajikistan }\end{array}$ & $\begin{array}{c}\text { GIKI } \\
\text { Pakistan }\end{array}$ \\
\hline \multicolumn{4}{|l|}{ System Description: } \\
\hline Volume of methane tank $\left(\mathrm{m}^{3}\right)$ & 10 & 10 & 10 \\
\hline Volume of slurry in methane tank $\left(\mathrm{m}^{3}\right)$ & 7 & 8 & 0.8 \\
\hline \multicolumn{4}{|l|}{ Parameters: } \\
\hline Period of analysis (years) & 10 & 10 & 10 \\
\hline Excess Inflation $(i)$ & 0 & 0 & 0 \\
\hline Discount Rate $(d)$ & $10 \%$ & $10 \%$ & $10 \%$ \\
\hline \multicolumn{4}{|l|}{ And Capital Cost: } \\
\hline \multicolumn{4}{|l|}{ Hardware (methane tank, pipes, } \\
\hline Transportation: $(\$)$ & 100 & 100 & 10 \\
\hline Installation: (\$) & 100 & 100 & 10 \\
\hline Total: $(\$)$ & 600 & 770 & 90 \\
\hline \multicolumn{4}{|l|}{ Operation and Maintenance: } \\
\hline Annual Cost $(\$)$ & 20 & 25 & 10 \\
\hline Discount factor $(\mathrm{Pa})$ & 6.14 & 6.14 & 6.14 \\
\hline Present Worth $(\$)$ & 122.8 & 153 & 61.4 \\
\hline \multicolumn{4}{|l|}{ Fuel: } \\
\hline Annual Fuel cost (\$) & 0 & 0 & 0 \\
\hline Present Worth (\$) & 0 & 0 & 0 \\
\hline \multicolumn{4}{|l|}{ Replacements: } \\
\hline Items & Pipes & Pipes Mixer & Pipes \\
\hline Duration (Years) & 5 & 5 & 5 \\
\hline Cost $(\$)$ & 50 & 30 & 5 \\
\hline $\operatorname{Pr}$ & 0.62 & 0.62 & 0.62 \\
\hline PW & 31 & 0.62 & 3.1 \\
\hline \multirow[t]{3}{*}{ Total $(\$)$} & 31 & 31 & 3.1 \\
\hline & & 18.6 & \\
\hline & & 49.6 & \\
\hline Total Life-Cycle Cost $(\$)$ & 753.8 & 973 & 154.5 \\
\hline Annualization Factor $(\mathrm{Pa})$ & 6.14 & 6.14 & 6.14 \\
\hline Annualized Life-Cycle Cost (ALCC):(\$) & 122.8 & 158 & 25 \\
\hline
\end{tabular}

Table 2: Technical parameters of investigated digesters and costs of methane extracted from biogas.

\begin{tabular}{llcc}
\hline Sr\# & \multicolumn{1}{c}{ Digesters } & Volume of methane tank $\left(\mathbf{m}^{\mathbf{3}}\right)$ & $\begin{array}{c}\text { Cost of methane } \\
\text { \$/Thousand }\left(\mathbf{m}^{\mathbf{3}}\right)\end{array}$ \\
\hline 1 & Vahdat district (Tajikistan) & 10 & 95 \\
2 & Rudaki district (Tajikistan) & 95 & 86 \\
3 & GIK Institute (Pakistan) & 10 & 102 \\
4 & Natural gas (USA at 1980-2005) & 01 & $80-280$ \\
\hline
\end{tabular}

\section{CONCLUSION}

The utilization of biogas that contains actually the solar energy reserved in the biomass as a result of photosynthetic process is practically very important for developed as well as developing countries.A recent trend in the power industry is the production of small-scale biogas plants that can satisfy the needs of one or several families living in the 
countryside.Life-cycle cost analysis of three biogas digesters showed that the cost of biogas depends on the construction of digesters, the size of methane tank and the heating of the slurry. It was found that the cost of methane extracted from biogas is in the range of US\$86-102/thousand $\mathrm{m}^{3}$ and is comparable with the cost of natural gas. Biogas digesters can be constructed and installed, in principle, for every family and there is no need to build long gas pipe lines.

\section{REFERENCES}

[1] Krepis I.B. Sun for men. Shtiintsa, Kishinev, USSR, 1989.

[2] Navickas. K. "Biogas for farming, energy conversion and environment protection." Bioplin, tehnologija in okolje, 29 November, Rakican, Riga, Latvia, 2007. International symposium, Biogas, technology and environment, University of Maribor, Faculty of Agriculture. 2007.

[3] Markvart T. Solar electricity. 6. John Ailey \& Sons Ltd., England, 2000.

[4] Twidell J. and Weir T. Renewable Energy Resources. Great Britain at the University Press, Cambridge, 1986.

[5] Krepis I.B. Potentialities of biogas production, News of Academy of Sciences of USSR, No.1 (1979), pp.103-112. 1 (1979): 103-12.

[6] Karimov Kh.S., Akhmedov Kh.M., Marupov R. "Renewable Energy Resources in the Republic of Tajikistan." State and Perspectives, Research \& Development Centre Information of the Republic of Tajikistan, №36 (1079)-T96, Dushanbe, Tajikistan, 1993, p.16.(In Russian).

[7] Dubrovskiy V.S., Viestur U.E., "Coversion of agricultural wastes into methane." Znanie, Riga, USSR, 1988.

[8] Barotfi I., Rafai, P. "Energy Saving Technologies in the farms." Nauka, Moscow,USSR, (1988).

[9] Berkovsky B.M., Kuzminov V.A., "Renewable Energy Resources for Man." Nauka, Moscow, USSR, (1987).

[10] Baader V., Done E., Brennderfer M., "Biogas: Theory and Practice.”, Kolos, Moscow, USSR, (1982).

[11] Tiwari G.N. "Solar Energy Fundamentals, Design, Modeling and Applications." Narosa Publishing House, New Delhi, India, (2002).

[12] Karimov Kh., Abid M., "Potentialities of biogas technology. Production and utilization of biogas.” VDM Verlag Dr.Muller Aktiengesellschaft \& Co. KG, Germany,( 2009).

[13] Karimov Kh., Abid M. "Biogas digester with simple solar heater". IIUM Engineering Journal Vol. 13, No. 2, 2012. 13.2 (2012). 